\title{
Welfare in Danish Dairy Herds 3. Health Management and General Routines in 1983 and 1994
}

\author{
By J.F. Agger and L. Alban
}

Department of Anımal Science and Anımal Health, Division of Ethology and Health, The Royal Veterinary and Agricultural University, Frederıksberg, Denmark.

\begin{abstract}
Agger, J.F. and L. Alban: Welfare in Danish dairy herds 3. Health management and general routines in 1983 and 1994. Acta vet. scand. 1996, 37, 79-97. - This paper presents the third part of descriptive results of questionnaire surveys in 152 Danish dairy herds in 1983 and in 2148 dairy herds in 1994. Focus is on workıng routınes related to health management and the close environment of the cows The variables are grouped in 6 categories as man power, bedding, water supply, manure handling, health management routınes, and the farmers' age and their opınion about health and welfare of the darry cows The results show that the husbands did the major parts of the job in the herds. Permanent laborers were mainly hired in cubicle and deep bed farms, while it was more common to hire a relief man (short term basis) in tie stall herds $-1 \mathrm{e}$ in the generally smaller herds The average time spent on milkıng and feeding per cow per day ranged from $5.2 \mathrm{~min}$ in cubicle houses and $5.4 \mathrm{~min}$ in deep bed houses to $99 \mathrm{~min}$ in tie stall houses The time per cow per day seemed to have been reduced by approximately $43 \%$ during the 11 year period. Straw was the primary choice of bedding, and the use varied much among the herds In tie stall houses with open dung channel and concrete floor the dally average use of straw was $174 \mathrm{~kg}$ per cow. Only $37.0 \%$ of the farmers used bedding for the heifers Water supply seemed to be well installed in all houses, and dung removal was highly automated Apart from milkıng and feedıng tımes the farmers looked after the cows on average twice a day. The farmers primarily looked for cows in heat, signs of disease, calving, and abnormal lyıng and raising patterns At night 87.7\% of tie stall farmers and $80.8 \%$ of cubicle house farmers were likely to check the cows, particularly with respect to calving In deep bed systems only $585 \%$ would check the cows at night. Contrary to this, farmers looked after pastured heifers less frequently. Farmers were generally concerned that the cows had a dry period The average length stated was 66 weeks Farmers were generally satisfied with the health and welfare of the cows The answers also indicated that farmers differentiated between the 2 concepts, as the correlation between welfare and health was only $r=034(p<0.001)$
\end{abstract}

cow; care; descriptive epidemiology; cattle; animal welfare; disease prevention; questionnaire; survey; surveillance.

\section{Introduction}

In order to understand the complex biology of production diseases in dairy cows that impact on the level of welfare, it is necessary to describe environment and management conditions and their frequencies in detall. A well planned housing design provides the dairy herd with good access to feed and water, a clean, dry, comfortable and peaceful resting area, and good ventilation. Most other things in the design of dairy housing are done for the manager, such as simple animal handling and observa- 
tion, simple animal 1solation and restraint, easy feed delivery, and easy waste collection and removal (McFarland 1995).

As an example, moisture level and temperature are 2 specific environmental factors that are shown to have a great impact on the relationship between housing and mastitis (Thomas et al. 1983, Jarrett 1984, Smith et al. 1985, Francis et al. 1981). Bacteria require food, moisture, and heat to survive and multiply. Humidity is dependent on the design of the stall and also on the working routines of the farmer, the use intensity of the stall (animals per square meter), the ventilation system including simple routines of opening/closing the windows, cleaning procedures, and use of water, etc. In this way there is a close, but not always clear and measurable, relationship between housing, caring, management, health status, and welfare of the herd. Riemann et al. (1985) found that there was a positive relationship between the farmers' caring for the cows and the frequency of ketosis. The authors explained this by a more careful disease recording in herds with a high care-index. As another example, Dodd et al. (1984) found that daily removal of soiled saw dust bedding from the rear $1 \mathrm{~m}$ of the stall and replacement with fresh sawdust resulted in reduction of coliform numbers from $>10^{8}$ per gram to approximately $10^{6}$. This resulted in an apparent $90 \%$ reduction in clinical coliform cases of mastitis. Generally it is estımated that pathogen densities greater than 1 million per gram of bedding would be required for an organism to pose a substantial threat (Bramley 1985). Housing cows on sand resulted in a 4-fold lower incidence of clinical coliform mastitis compared with sawdust. It is also a general observation that housed cattle are at greater risk of environmental mastitis than cattle on pasture (Hogan \& Smith 1987).

This paper presents the third part of results of surveys carried out in 1983 in 152 dairy herds and in 1994 in 2148 dairy herds in Denmark. The first part of the surveys was dealt with in Alban \& Agger (1996a) and considered disease management routines and welfare, and the second part dealt with housing systems, grazing procedures and welfare (Alban \& Agger 1996b). The purpose of this third part was to describe farmers' working routines that relate to health management and to the close environment that are considered important for the welfare of the cows. Health management may be defined as working routines related to 1) maintaining a high level of resistance to microorganisms and metabolic stress, 2) maintaining a low level of microorganisms on the cow and in the environment, 3) preventing the introduction of microorganisms into the herd, and 4) preventing unbalanced rations in the feeding plan. Simonsen (1993) defined welfare as the sum of positive and negative experiences that an animal may have. Welfare cannot be evaluated on a single trait. It rather needs to be judged from several factors within the topics of physiology, ethology and disease. This view is supported by many other researchers (Duncan \& Dawkins 1983, Broom 1986 \& 1991, Broom \& Johnson 1993, Blackshaw 1986, Sandøe \& Simonsen 1992, Stmonsen 1982 \& 1990). Many welfare parameters are diffıcult and time consumıng to measure, and are not readily available. The level of welfare in the present project is measured as the treatment incidence rate of disease. A reduced disease incidence, all things considered, improves the welfare of the animals.

\section{Materials and methods}

The materials and methods were described in detail in Alban \& Agger (1996a). Briefly reviewed, data from surveys in 1983 in 152 tie stall dairy herds and in 1994 in 2148 dairy herds were included. The farmers were asked about types and conditions of housing systems, 
the cows' environment, and about disease, health, and more general management routines. The data were filed and analyzed using the Statistical Analysis System software package ( $S A S$ Institute Inc. 1989).

Each management factor was evaluated in relation to the type of housing in the 1994 survey. The herd size was also considered in a few relevant situations. Fifteen herds among the 2148 interviewed dairy farmers in the 1994 survey, which had mixed types of housing, were excluded from the analysis. Thus analysis of the 1994-data included 2133 herds. Statistical evaluation was done by using Chi-square test and Pearson standardized residual analysis (Christensen 1990) of each table under the assumption that the studied herds were 1 multinomial. Analysis of variance for unballanced data and correlation analysis were used as well. Variables with no strong difference between types of houses were collapsed. The management variables were grouped in 6 categories. However, the authors are aware that some variables may belong to more than 1 of these groups. Most information from the 1994-study is given in the tables and not repeated in the text.

\section{Results}

\section{Manpower}

Who is primarily taking care of the dairy cows? The 1983-study of tie stall farms showed that the husbands participated in the work with the cows in $94.7 \%$ of the herds. The wife participated in $11.8 \%$ of the farms, the farm laborer in $9.2 \%$, and the children in $1.7 \%$ of the farms. The responsibilities were shared among 2 or more persons in $17.4 \%$ of the herds. In the 1994-study (Table 1) there was a significant $(p<0.001)$ association between type of housing and the personelle taking care of the cows. Residual analysis shows that in cubicle houses the husband alone participated signifi-

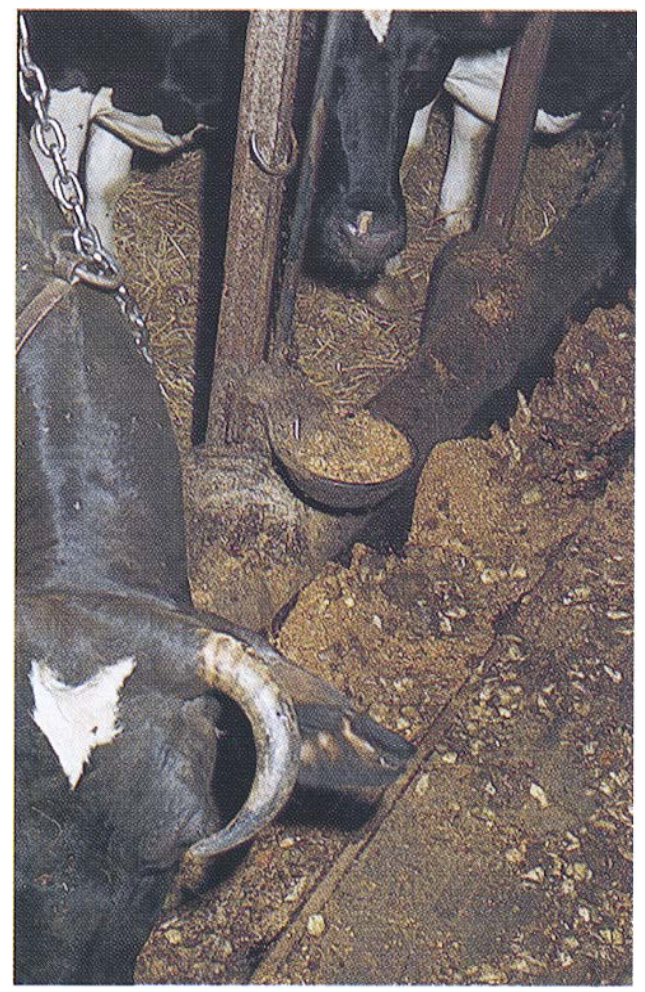

F1gure 1. Management routıne checks to maintain a well functioning environment in the cow stall are important. As an example, these cows may suffer from lack of water for several hours. (Photo by $J F$ Agger)

cantly less, and the farm laborer alone or together with the husband participated significantly more than in the other 2 types of cow houses. The husband participated in the work in $90.2 \%$ of the tie stall herds, in cubicle houses in $77.8 \%$, and in deep bed systems in $87.6 \%$ of the herds. Comparing the 3 systems, the biggest difference was that extra personnel was hired in $24.9 \%$ of the tie stall farms, in $32.3 \%$ of the deep bed farms and in $53.4 \%$ of the cubicle house farms.

How many hours are usually spent on feeding and milking in the morning and evening? This relates to the herd size, 
Table 1. Persons taking care of the cows.

\begin{tabular}{|c|c|c|c|c|c|c|}
\hline \multirow[t]{3}{*}{ Person(s) } & \multicolumn{6}{|c|}{ Type of cow house } \\
\hline & \multicolumn{2}{|c|}{ Tre stall house } & \multicolumn{2}{|c|}{ Cubicle house } & \multicolumn{2}{|c|}{ Deep bed house } \\
\hline & No herds & $\%$ & No herds & $\%$ & No herds & $\%$ \\
\hline Husband & 1255 & 66.9 & $80 *$ & 41,5 & 40 & 61.5 \\
\hline Wife & 17 & 09 & 0 & 00 & 1 & 1.5 \\
\hline Husband and wife & 137 & 73 & 10 & 52 & 3 & 4.6 \\
\hline Farm laborer & 159 & 85 & $43^{*}$ & 22.3 & 7 & 10.8 \\
\hline Husband and farm laborer & 285 & 15.2 & $58^{*}$ & 301 & 13 & 200 \\
\hline Wife and farm laborer & 7 & 0.4 & 0 & 0.0 & 0 & 0.0 \\
\hline Husband, wife and farm laborer & 15 & 0.8 & 2 & 1.0 & 1 & 1.5 \\
\hline Total & 1875 & 100 & 193 & 100 & 65 & 100 \\
\hline
\end{tabular}

$* \mathrm{p}<0.001$.

Table 2. The average tıme (min) for milkıng and feedıng per cow per day by type of housıng system.

\begin{tabular}{lccc}
\hline Time and associations & \multicolumn{3}{c}{ Type of cow house } \\
\cline { 2 - 4 } & Tie stall house & Cubicle house & Deep bed house \\
\hline Man min per cow per day 1 & $99^{*} \pm 62$ & $5.2 \pm 1.8$ & $54 \pm 22$ \\
Correlation between herd size & -0.51 & -054 & -053 \\
and man min per cow per day & 45.4 & 90.1 & 800 \\
Mean herd size & 1871 & 192 & 65 \\
Number of herds & & & \\
\hline
\end{tabular}

1 Mean \pm standard deviation.

* Tie stall farms were statıstıcally sıgnificantly different from the 2 other groups $(\mathrm{p}<0.001)$

and this variable was therefore considered also. In the 1983-study the estimated average man min used for milking and feeding per cow per day was $14.2 \mathrm{~min}$ in tie stall herds with traditional dung channel and $14.6 \mathrm{~min}$ in tie stall herds with gratings or slats behind the cows. The estimates for milking, feeding, and cleaning were $16.9 \mathrm{~min}$ and $16.0 \mathrm{~min}$ respectively. The average herd size was 31.6 cows. In the 1994-study (Table 2) the average time spent per cow in tie stall herds $(9.9 \mathrm{~min}$ ) was larger $(\mathrm{p}<0.001)$ than in loose housing systems. The Pearson correlation coefficient showed a negative relationship $(p<0.001)$ between herd size and man min per cow per day. The correlation coefficient was about the same $(r=-0.51$ to -0.53 ) for the 3 housing systems.

Do you use hired labor in the cow house? In the 1983 -study $66.4 \%$ of the tie stall herds never hired people to work on the farms. 3.8\% hired people periodically, and $29.8 \%$ constantly. In the 1994-study (Table 3 ) tie stall herds used constant hired labor least, and cubicle herds constantly more than deep bed farms $(\mathrm{p}<0.02)$.

How often do you call a relief man to take care of the cows? In 1983 the farmers on average hired a relief man 14.5 days per year (range 0-91). In 1994 (Table 4) there was an association between the use of a relief man 
Table 3. Frequency of hirıng labor in the cow houses

\begin{tabular}{|c|c|c|c|c|c|c|}
\hline \multirow[t]{3}{*}{ Frequency } & \multicolumn{6}{|c|}{ Type of cow house } \\
\hline & \multicolumn{2}{|c|}{ Tre stall house } & \multicolumn{2}{|c|}{ Cubicle house } & \multicolumn{2}{|c|}{ Deep bed house } \\
\hline & No herds & $\%$ & No herds & $\%$ & No herds & $\%$ \\
\hline Constant & $661^{*}$ & 35.3 & $134^{*}$ & 69.8 & 31 & 47.7 \\
\hline Periodically & 226 & 12.2 & 19 & 99 & 9 & 13.8 \\
\hline Never & $983 *$ & 52.6 & $39 *$ & 20.3 & 25 & 385 \\
\hline Total & 1870 & 100 & 192 & 100 & 65 & 100 \\
\hline
\end{tabular}

$* p<002$.

Table 4. Use of relief man to take care of the cows by type of housing.

\begin{tabular}{|c|c|c|c|c|c|c|}
\hline \multirow[t]{3}{*}{ Use of relief man } & \multicolumn{6}{|c|}{ Type of cow house } \\
\hline & \multicolumn{2}{|c|}{ Tie stall house } & \multicolumn{2}{|c|}{ Cubicle house } & \multicolumn{2}{|c|}{ Deep bed house } \\
\hline & No herds & $\%$ & No herds & $\%$ & No herds & $\%$ \\
\hline Use & 1152 & 61.4 & $80^{*}$ & 41.5 & 35 & 54.8 \\
\hline Did not use & 710 & 37.9 & $110^{*}$ & 570 & 30 & 45.2 \\
\hline Did not answer & 13 & 0.7 & 3 & 1.5 & 0 & 0.0 \\
\hline Total & 1870 & 100 & 193 & 100 & 65 & 100 \\
\hline $\begin{array}{l}\text { Mean days per year } \\
\text { among herds using a }\end{array}$ & \multicolumn{2}{|c|}{$18.8(\mathrm{sd}=34.4)$} & \multicolumn{2}{|c|}{$253(\mathrm{sd}=45.4)$} & \multicolumn{2}{|c|}{$139(\mathrm{sd}=146)$} \\
\hline relief man (NS) & \multicolumn{2}{|c|}{ Range: $1-365$} & \multicolumn{2}{|c|}{ Range: $1-360$} & \multicolumn{2}{|c|}{ Range: $1-60$} \\
\hline
\end{tabular}

$* \mathrm{p}<0001$. NS $=$ Not significant.

and herd type $(\mathrm{p}<0.001)$. It was most common to call a relief man in tie stall farms - i.e. the system which made the least use of permanent hired labor (Table 3). Cubicle house farmers made the least use of relief men. There was no significant difference between the mean number of days hiring a relief man among herds using this option. However, there was a wide range within each type of housing system.

\section{Bedding}

How much bedding was used per cow per day? In the 1983-study the average amount was $1.5 \mathrm{~kg}$ long straw per cow per day in tie stall farms with traditional open dung channel and cement floor without rubbermats. Only $5.3 \%$ of the herds used chopped straw. In 1994 (Table 5) there was a large variation in the use of bedding within each type of housing. Deep bed farms used most straw, and tie stall herds with gratings or slats behind the cows and cubicle herds with slats used the smaller amount of bedding. The least amount of bedding was used with saw dust and when the concrete floor was covered with rubber mats. Chopped straw was used in $53.8 \%$ of the herds. How much bedding was used per heifer per day? This question was not posed in 1983. In 1994 (Table 6) there was a significant association between the use of bedding for 
Table 5. Amount of bedding per day ( $\mathrm{kg}$ ) for cows by type of housing for the most frequent observed comb1nations

\begin{tabular}{lcccc}
\hline Type of housing* & No herds & Mean $(\mathrm{kg})$ & $\mathrm{Sd}(\mathrm{kg})$ & Range $(\mathrm{kg})$ \\
\hline $\begin{array}{l}\text { Tie stall house, open dung } \\
\text { channel, concrete and straw }\end{array}$ & 1020 & $174^{\mathrm{a}}$ & 106 & $01-10$ \\
$\begin{array}{l}\text { Tie stall house, slats, concrete } \\
\text { and straw }\end{array}$ & 52 & $0.74^{\mathrm{c}}$ & 0.59 & $01-3$ \\
$\begin{array}{l}\text { Tie stall house, gratings } \\
\text { concrete and straw }\end{array}$ & 389 & $072^{\mathrm{c}}$ & 085 & $0-10$ \\
$\begin{array}{l}\text { Tie stall house, gratıngs, } \\
\text { concrete and saw dust }\end{array}$ & 24 & $0.02^{\mathrm{d}}$ & 01 & $0-05$ \\
$\begin{array}{l}\text { Tie stall house, gratıngs, rubber } \\
\text { mats (beddıng material }\end{array}$ & 70 & $0.3^{\mathrm{d}}$ & 0.4 & $0-2$ \\
$\begin{array}{l}\text { unspecified) } \\
\begin{array}{l}\text { Cubicle house, concrete and } \\
\text { straw }\end{array}\end{array}$ & 131 & $0.8^{\mathrm{c}}$ & 1.03 & $01-7$ \\
\begin{tabular}{l} 
Deep bed house \\
\hline
\end{tabular} & 61 & $7.83^{\mathrm{b}}$ & 2.51 & $2-15$ \\
\hline
\end{tabular}

* 386 herds had missing information.

a,b,c,d Different letters indicate statıstıcally significant different means $(p<0.01)$.

Table 6. Amount of bedding $(\mathrm{kg})$ per day for heifers by type of heifer housing system. Only herds with 1 type of housing for heifers are included.

\begin{tabular}{|c|c|c|c|c|c|c|}
\hline \multirow[t]{3}{*}{ Beddıng } & \multicolumn{6}{|c|}{ Type of helfer house } \\
\hline & \multicolumn{2}{|c|}{ Tie stall house } & \multicolumn{2}{|c|}{$\begin{array}{l}\text { Cubicle house } \\
\text { (Boxes) }\end{array}$} & \multicolumn{2}{|c|}{ Deep bed house } \\
\hline & No herds & $\%$ & No herds & $\%$ & No herds & $\%$ \\
\hline Beddıng & 594 & 74.9 & 22 & 23 & 134 & 775 \\
\hline No beddıng & 123 & 15.5 & 920 & 97.1 & 0 & 0.0 \\
\hline Did not answer & 76 & 9.6 & 6 & 0.6 & 39 & 225 \\
\hline Total & 793 & 100 & 948 & 100 & 173 & 100 \\
\hline $\begin{array}{l}\text { Mean } \pm \mathrm{sd}(\mathrm{kg}) \text { among herds } \\
\text { using straw }\end{array}$ & \multicolumn{2}{|c|}{$099 \pm 0.87$} & \multicolumn{2}{|c|}{$1.23 \pm 1.38$} & \multicolumn{2}{|c|}{$4.26 \pm 277$} \\
\hline
\end{tabular}

Pearson standardized residural analysıs showed that all observatıons were statıstıcally significantly different from the expected.

heifers and type of housing $(\mathrm{p}<0.001)$. Bedding was used least in cubicle houses (boxes, $2.3 \%$ ), and most common in tie stall and deep bed houses. The average amount of straw in deep bed systems was statistically significantly higher $(\mathrm{p}<0.001)$ than in cubicle farms and in tie stall herds. Heifers in loose housing systems were mainly kept in boxes. An over all estimate of 2027 farmers answering this question shows that $63.0 \%$ did not use bedding for the heifers. 
Table 7. Water supplied to the cows indoor.

\begin{tabular}{|c|c|c|c|c|c|c|}
\hline \multirow{3}{*}{$\begin{array}{l}\text { Water supply } \\
\text { method }^{1}\end{array}$} & \multicolumn{6}{|c|}{ Type of cow house } \\
\hline & \multicolumn{2}{|c|}{ T1e stall house } & \multicolumn{2}{|c|}{ Cubicle house } & \multicolumn{2}{|c|}{ Deep bed house } \\
\hline & No herds & $\%$ & No herds & $\%$ & No herds & $\%$ \\
\hline Drınkıng bowl & 1840 & 98.2 & 26 & 135 & 6 & 9.2 \\
\hline Trough & 23 & 1.2 & 146 & 756 & 53 & 81.6 \\
\hline Bowl and trough & 0 & 0.0 & 11 & 57 & 0 & 00 \\
\hline Other & 11 & 06 & 10 & 52 & 6 & 92 \\
\hline Total & 1875 & 100 & 193 & 100 & 65 & 100 \\
\hline
\end{tabular}

1 All observations were statıstıcally sıgnificantly different from expected

Table 8. Frequency for the farmer's check of drınkıng bowls.

\begin{tabular}{|c|c|c|c|c|c|c|}
\hline \multirow{3}{*}{$\begin{array}{l}\text { Number of checks } \\
\text { per year }\end{array}$} & \multicolumn{6}{|c|}{ Type of cow house } \\
\hline & \multicolumn{2}{|c|}{ Tie stall house } & \multicolumn{2}{|c|}{ Cubicle house } & \multicolumn{2}{|c|}{ Deep bed house } \\
\hline & No herds & $\%$ & No herds & $\%$ & No herds & $\%$ \\
\hline $1-12$ & 849 & 46.1 & $7 *$ & 18.9 & 2 & 33.3 \\
\hline $13-52$ & 295 & 16.0 & 10 & 270 & 1 & 167 \\
\hline$>52$ & 393 & 21.4 & 11 & 297 & 3 & 500 \\
\hline Did not check & 192 & 10.4 & 6 & 162 & 0 & 0.0 \\
\hline Did not answer & 111 & 6.0 & 3 & 81 & 0 & 0.0 \\
\hline Total & 1840 & 100 & 37 & 100 & 6 & 100 \\
\hline
\end{tabular}

${ }^{*} \mathrm{p}<0.01$

\section{Water supply}

How is water supplied to the cows indoor? In the 1983-study $90.8 \%$ of the herds had drinking bowls installed. In 1994 (Table 7) there was an association $(p<0.001)$ between type of housing and indoor method of water supply. Almost all tie stall farms used drinking bowls, while the majority of loose house systems used a trough. The amount of water supplied per min from drinking bowls was known in 844 herds. The average yield per min was 14.7 liter $(\mathrm{sd}=4.82)$.

How is water supplied to the cows outdoor? This question was not posed in 1983. In 1994 this question was answered by $79.9 \%$ of the farmers. There was no statistically significant association $(p=0.20)$ between type of housing and water supply outdoor. The major1ty provided water from a trough $(83.1 \%)$, and the rest used drinking bowls or other procedures.

How often do you check the function of the drinking bowls? This question was not asked in 1983. In 1994 (Table 8) there was an association $(\mathrm{p}=0.03)$ between farmers' check of drinking bowls and herd type. The table includes only farms with drinking bowls. Deep bed farmers checked the drinking bowls relatively most frequently. 
Table 9. Method of dung removal in tie stall farms with traditional open dung channel.

\begin{tabular}{lcc}
\hline Method & No herds & $\%$ \\
\hline By shovel & 129 & 11.4 \\
$\begin{array}{l}\text { Motor scraper } \\
\text { or other semı } \\
\text { automized } \\
\text { system }\end{array}$ & 469 & 41.4 \\
$\begin{array}{l}\text { Automatic } \\
\text { system }\end{array}$ & 507 & 44.8 \\
$\begin{array}{l}\text { Mixture of } \\
\text { above methods }\end{array}$ & 20 & 1.8 \\
$\begin{array}{l}\text { Did not answer } \\
\text { Total }\end{array}$ & 7 & 06 \\
\hline
\end{tabular}

ing $20.6 \%$ also used shuffle or a motor scraper. In 1994 (Table 9) the farmers physically had to do the complete job in only $11.4 \%$ of 1132 tie stall houses with traditional dung channel. This means there was a high level of automized dung removal.

\section{Health management routines}

When do you survey the cows besides milkings/feedings? In the 1983-study $27.8 \%$ of the farmers did not check the cows besides milking and feeding. $41.9 \%$ checked 1 time, $29.1 \%$ checked 2 times, and $1.2 \%$ checked 3 times. The average number of inspections was 1.0 per day, and the average in-

Table 10. Relative frequencies for the farmers checks for important clinical signs of the cows.

\begin{tabular}{|c|c|c|c|c|c|c|}
\hline \multirow[t]{3}{*}{ Clınıcal sıgns } & \multicolumn{6}{|c|}{ Type of cow house } \\
\hline & \multicolumn{2}{|c|}{ Tie stall house } & \multicolumn{2}{|c|}{ Cubicle house } & \multicolumn{2}{|c|}{ Deep bed house } \\
\hline & No herds & $\%$ & No herds & $\%$ & No herds & $\%$ \\
\hline Cows in heat & 1706 & 91.0 & 175 & 90.7 & 57 & 877 \\
\hline Calving & 451 & 24.1 & 73 & 37.8 & 22 & 33.8 \\
\hline Eatıng and rumınatıng & 466 & 245 & 31 & 16.1 & 15 & 23.1 \\
\hline Normal lyıng and raising behaviour & 620 & 33.1 & 63 & 32.6 & 27 & 415 \\
\hline Condition of faeces & 132 & 7.0 & 1 & 0.5 & 2 & 31 \\
\hline Condition af the hair coat & 52 & 2.8 & 2 & 1.0 & 1 & 1.5 \\
\hline Signs of disease & 898 & 47.9 & 59 & 30.6 & 24 & 369 \\
\hline Other signs/conditions & 275 & 14.7 & 19 & 9.8 & 7 & 10.8 \\
\hline Distribution of ration among cows & 210 & 11.2 & 14 & 7.3 & 2 & 31 \\
\hline Total* & 1875 & - & 193 & - & 65 & - \\
\hline
\end{tabular}

${ }^{*}$ As there may be more than one reason to check the cows, the percentage add up to more than 100 .

\section{Manure handling}

How is the dung removed in herds with traditional dung channel? In 1983 $18.6 \%$ of tie stall houses with traditional dung channel used man power only, $61.7 \%$ used motor scraper or other semi automatic systems, $16.9 \%$ had automatic systems, and $2.8 \%$ used other methods. Among herds with slats or gratings $79.4 \%$ did nothing extra, while the remain- spection time was $11 \mathrm{~min}(\mathrm{sd}=7 \mathrm{~min})$. In the 1994-study this variable was re-categorized into the number of times the cows were surveilled during the day. The range was from 1 to 4 times a day. The average varied from 2 in tie stall herds to 2.1 in cubicle farms, and 2.3 times per day in deep bed farms. The farmers checked the cows at noon and in the evening in $51.9 \%$ of the herds. 
Table 11 Reasons for the farmers to check cows at night

\begin{tabular}{|c|c|c|c|c|c|c|}
\hline \multirow{3}{*}{$\begin{array}{l}\text { Reason for night } \\
\text { check of cows }\end{array}$} & \multicolumn{6}{|c|}{ Type of cow house } \\
\hline & \multicolumn{2}{|c|}{ Tie stall house } & \multicolumn{2}{|c|}{ Cubicle house } & \multicolumn{2}{|c|}{ Deep bed house } \\
\hline & No herds & $\%$ & No herds & $\%$ & No herds & $\%$ \\
\hline Sick cows & 374 & 199 & 26 & 13.5 & 11 & 16.9 \\
\hline Calving cows & 1598 & 852 & 151 & 78.2 & 35 & 53.8 \\
\hline Other reasons & 49 & 26 & 6 & 31 & 1 & 1.5 \\
\hline Do never/seldom check cows & 230 & 12.3 & 37 & 192 & 27 & 415 \\
\hline Total* & 1875 & - & 193 & - & 65 & - \\
\hline
\end{tabular}

* As there may be more than one reason to check the cows, the percentages may add up to more than 100 .

Table 12. Methods of restrictıng the rations for dry cows

\begin{tabular}{|c|c|c|c|c|c|c|}
\hline \multirow[t]{3}{*}{ Method of retriction } & \multicolumn{6}{|c|}{ Type of cow house } \\
\hline & \multicolumn{2}{|c|}{ Tie stall house } & \multicolumn{2}{|c|}{ Cubicle house } & \multicolumn{2}{|c|}{ Deep bed house } \\
\hline & No herds & $\%$ & No herds & $\%$ & No herds & $\%$ \\
\hline Concentrate and roughage & 1408 & 759 & 135 & 70 & 37 & 56.9 \\
\hline Concentrate only & 388 & 207 & 40 & 20.7 & 20 & 308 \\
\hline Roughage only & 28 & 1.5 & $8^{*}$ & 4.1 & 0 & 00 \\
\hline No restriction & 47 & 2.5 & $10^{*}$ & 5.2 & $7^{*}$ & 10.8 \\
\hline Did not answer & 4 & 0.2 & 0 & 00 & 1 & 1.5 \\
\hline Total & 1875 & 100 & 193 & 100 & 65 & 100 \\
\hline
\end{tabular}

${ }^{*} \mathrm{p}<0.01$

Who is looking after the cows? In 1994 the farmers participated in looking after the cows besides milking and feeding times in $97.2 \%$ of the herds. The farm laborer partic1pated in checking the cows in $28.6 \%$ of the herds. It was always the same person(s) that checked the cows in $94.3 \%$ of the herds. This question was not asked in 1983.

What are you looking for when you check the cows? As the farmers may look for more signs at the same inspection, the total percent within each housing system in 1994 (Table 10) may sum to more than 100 . The 4 major concerns in all 3 housing systems were to identify cows in heat, to observe signs of disease, to look after calving cows, and to watch for abnormal lying and raising patterns. This question was not posed in 1983.

Do you get up at night to check the cows? Table 11 shows, as in Table 10, that the farmers were mainly concerned with the reproduction in the herd. Apparently sıck anımals are managed during day time. Deep bed farmers had less tendency to check the cows at night compared to tie stall farms and cubicle farms. This question was not asked in 1983.

How often do you look after the heifers on pasture during summer? There was no association $(p=0.20)$ between type of housing and the frequency at which the farmers looked after the heifers on pasture. However, daily checks of the grazing heifers seemed to be 
Table 13. Shearing frequency and part of the body by type of housing

\begin{tabular}{|c|c|c|c|c|c|c|c|c|c|}
\hline \multirow[t]{3}{*}{ Shearnng } & \multicolumn{9}{|c|}{ Type of cow house } \\
\hline & \multicolumn{3}{|c|}{ Tie stall house } & \multicolumn{3}{|c|}{ Cubicle house } & \multicolumn{3}{|c|}{ Deep bed house } \\
\hline & No herds & $\% *$ & Mean & No herds & $\% *$ & Mean & No herds & \%* & Mean \\
\hline \multicolumn{10}{|l|}{ Frequency } \\
\hline Once a year & 1270 & 68.0 & - & 58 & 300 & - & 11 & 170 & - \\
\hline$>$ once a year & 209 & 11.0 & - & 17 & 88 & - & 5 & 7.8 & - \\
\hline Do not shear the hair & 396 & 21.0 & - & 118 & 610 & - & 49 & 75.0 & - \\
\hline \multicolumn{10}{|l|}{ Part of body } \\
\hline Udder & 85 & 4.5 & 2.2 & 10 & 52 & 17 & 2 & 31 & 15 \\
\hline Ta1l & 242 & 13.0 & 2.8 & 31 & 160 & 19 & 4 & 62 & 15 \\
\hline Rump & 227 & 120 & 1.6 & 19 & 98 & 11 & 4 & 62 & 2.5 \\
\hline Whole body & 1183 & 630 & 1.2 & 36 & 190 & 1.1 & 8 & 120 & 1 \\
\hline Total & 1875 & - & - & 193 & - & - & 65 & - & - \\
\hline
\end{tabular}

* Percentages calculated in relation to "Total"

more common in deep bed farms $(56.9 \%)$ than in cubicle $(33.7 \%)$ and tie stall systems (44.7\%). 20.5\% attended the heifers every second day, $15.9 \%$ twice a week, $8.4 \%$ once a week, and $0.1 \%$ only every second week. This question was not asked in 1983.

Do you restrict the ration fed to dry cows? In the 1983 -study $79.5 \%$ of the farmers restricted the concentrate as the most frequently used procedure and usually in combination with a less frequent milking. In 1994 there was an association $(p<0.001)$ between the ration fed to cows at drying off and the type of housing (Table 12). The majority of farmers within all 3 types of housing restricted both concentrate and roughage. A total of $95.1 \%$ of the farmers restricted the concentrate ration, while only $75.8 \%$ restricted the roughage ration.

Do you give a special mineral supplement to dry cows? $33.2 \%$ of the farmers gave special mineral supplement to dry cows. This question was not asked in 1983.

How long time is the dry cow period in your herd? In 1983 the mean dry period was estimated to be 5.7 weeks. $14.9 \%$ had a dry period $\leq 4$ weeks, $20.1 \%$ of 5 weeks and $65 \%$ of $\geq 6$ weeks. In 1994 there was a weak association $(p=0.08)$ between length of the dry period and type of housing. The farmers were very concerned about a "resting period" for the cows before the next lactation. 88\% kept the cows dry for 6 or more weeks, and $12 \%$ of the herds dried the cows off $\leq 5$ weeks. The mean length of the dry period was 6.6 weeks.

How frequently do you shear the cows? - and - On which part(s) of the body do you shear the cows? In the 1983 -study $25.1 \%$ of the tie stall farmers did not cut the hair coat of the cows, $69.4 \%$ cut the hair once a year, $5.4 \%$ cut the hair 2-3 times per year. It was also found that $26 \%$ never cut the hair of the udder, $64.6 \%$ cut the hair coat on the udder once a year, and $9.4 \%$ cut the hair of the udder 2-3 times per year. The 1994-study: As the farmers may shear more parts of the cows, the percent may sum to more than 100 (Table 13). A total of $73.1 \%$ of the farmers sheared the cows at least once a year. Shearing was most common in tie stall herds compared to cubicle and deep bed farms. Among farmers that 
Table 14 Frequency and method of grooming the cows by type of housing

\begin{tabular}{|c|c|c|c|c|c|c|}
\hline \multirow[t]{3}{*}{ Grooming } & \multicolumn{6}{|c|}{ Type of cow house } \\
\hline & \multicolumn{2}{|c|}{ Tie stall house } & \multicolumn{2}{|c|}{ Cubicle house } & \multicolumn{2}{|c|}{ Deep bed house } \\
\hline & No herds & $\%$ & No herds & $\%$ & No herds & $\%$ \\
\hline \multicolumn{7}{|c|}{ Frequency (ttmes/year) } \\
\hline 0 (did not groom $)$ & 581 & 310 & 101 & 52.3 & 43 & 662 \\
\hline $1-12$ & 766 & 40.9 & 10 & 52 & 1 & 1.5 \\
\hline $13-26$ & 246 & 13.0 & 2 & 10 & 0 & 0.0 \\
\hline $27-52$ & 208 & 111 & 1 & 05 & 0 & 0.0 \\
\hline $53-364$ & 63 & 34 & 0 & 00 & 0 & 0.0 \\
\hline $365^{1}$ & 6 & 03 & 79 & 409 & 21 & 323 \\
\hline Did not answer & 5 & 03 & 0 & 00 & 0 & 00 \\
\hline \multicolumn{7}{|l|}{ Method } \\
\hline Rotatıng brush & 3 & 02 & 80 & 415 & 21 & 32.3 \\
\hline Vacuum cleaner & 264 & 141 & 1 & 05 & 0 & 00 \\
\hline Hand brush & 1063 & 567 & 11 & 57 & 3 & 46 \\
\hline Total & 1875 & $* *$ & 193 & $* *$ & 65 & ** \\
\hline
\end{tabular}

${ }^{1}$ Assumed da1ly, as the cows had free access to a rotatıng brush ${ }^{* *}$ More than one method may be used in the same herd Therefore the percentages may add up to more than 100 .

sheared the cows, it was most common to shear the whole body in all 3 housing systems, pr1marily in tie stall farms. Shearing of the tail and rump was less common, and it was least common to shear the udder.

How often do you groom the cows? and-How do you groom your cows? In the 1983-study $46.6 \%$ of the farmers never groomed the cows, $50.8 \%$ used a brush, and $2.6 \%$ used a vacuum cleaner. The farmers groomed the cows on average 31.4 times per year $(\mathrm{sd}=49.4)$. In 1994 (Table 14) grooming of the cows was most common in tie stall farms, mainly by use of a hand brush or a vacuum cleaner. Grooming was less common in cubicle house systems and least in deep bed systems. In those herds the cows widely benefitted from an installed rotatıng brush. The average number of groomings per year was $23.1(\mathrm{sd}=37.4)$ in tie stall farms, $315(\mathrm{sd}=123.9)$ in cubicle farms, and $348.5(\mathrm{sd}=77.2)$ in deep bed farms.
The farmer and his opinion about the herd Age of the farmers. In 1983 the mean age of the 152 farmers was 48.7 years $(\mathrm{sd}=9.8)$. In 1994 the mean age of all farmers was 45.6 years $(\mathrm{sd}=11.1$ years $)$. The mean age of tie stall farmers was 46.2 years $(\mathrm{sd}=11.1)$, cubicle house farmers 42.4 years $(\mathrm{sd}=9.6)$ and for deep bed farmers 38.4 years $(\mathrm{sd}=10.5)$.

Do you expect to be a dary farmer 5 years ahead? Over all $77.4 \%$ expected still to be in business 5 years ahead. Some of these, though, because they knew the son was prepared to take over the farm. Among the others, $13.7 \%$ said "no", and $8.8 \%$ "did not know". Among tie stall farmers only $74.9 \%$ expected to be in business 5 years ahead, while $95.9 \%$ of the cubicle house farmers and $92.3 \%$ of deep bed farmers expected to be in business 5 years ahead. The correlation coefficient between age of farmer and expectancy to be in business was $\mathrm{r}=-.48$. This question was not asked in 1983 . 
Table 15. Farmers' opinion of the use intensity of their stalls, by type of housing

\begin{tabular}{|c|c|c|c|c|c|c|}
\hline \multirow[t]{3}{*}{ Use intensity } & \multicolumn{6}{|c|}{ Type of cow house } \\
\hline & \multicolumn{2}{|c|}{ Tie stall house } & \multicolumn{2}{|c|}{ Cubicle house } & \multicolumn{2}{|c|}{ Deep bed house } \\
\hline & No herds & $\%$ & No herds & $\%$ & No herds & $\%$ \\
\hline Adequate & 1296 & 69.1 & 127 & 661 & 33 & 508 \\
\hline Too low & 144 & 7.7 & $31 *$ & 161 & $17^{*}$ & 26.2 \\
\hline Too high & 435 & 23.2 & 34 & 17.7 & 15 & 231 \\
\hline Total & 1875 & 100 & 192 & 100 & 65 & 100 \\
\hline
\end{tabular}

${ }^{*} \mathrm{p}<0.001$.

Table 16. Farmers' opinion with respect to health and welfare of cows, by type of housing

\begin{tabular}{|c|c|c|c|c|c|c|}
\hline \multirow[t]{3}{*}{ Level of satısfaction } & \multicolumn{6}{|c|}{ Type of cow house } \\
\hline & \multicolumn{2}{|c|}{ Tre stall house } & \multicolumn{2}{|c|}{ Cubicle house } & \multicolumn{2}{|c|}{ Deep bed house } \\
\hline & No herds & $\%$ & No herds & $\%$ & No herds & $\%$ \\
\hline \multicolumn{7}{|l|}{ Health. } \\
\hline Very satısfied & 300 & 16 & 30 & 15.5 & $21 *$ & 323 \\
\hline Satisfied & 1037 & 55.3 & 102 & 52.9 & 32 & 49.2 \\
\hline Medium & 448 & 23.9 & 48 & 24.9 & 12 & 18.5 \\
\hline Less satısfied & 83 & 4.4 & 12 & 6.2 & 0 & 00 \\
\hline Not satisfied & 7 & 0.3 & 1 & 0.5 & 0 & 0.0 \\
\hline \multicolumn{7}{|l|}{ Welfare } \\
\hline Very satısfied & $446^{*}$ & 238 & 62 & 321 & $53 *$ & 81.5 \\
\hline Satisfied & 1141 & 60.9 & 103 & 53.4 & $12 *$ & 18.5 \\
\hline Medium satısfied & 264 & 14.1 & 24 & 124 & $0 *$ & 0.0 \\
\hline Less satisfied & 20 & 1.1 & 4 & 21 & 0 & 0.0 \\
\hline Not satisfied & 4 & 0.2 & 0 & 00 & 0 & 0.0 \\
\hline Total & 1875 & 100 & 193 & 100 & 65 & 100 \\
\hline
\end{tabular}

$*(p<0.001)$.

What is your evaluation of the use intensity of the stall? There was an association $(\mathrm{p}<0.001)$ between farmers' opinion about the use intensity and the type of housing (Table 15). The major finding in the 1994-study was that approximately one fifth of the cubicle house and deep bed house farmers felt the use intensity was too low. This question was not posed in 1983.

How satisfied are you with the health situation of your cow herd? - and-How satisfied are you with the welfare situation of your cow herd? There was a statistically significant association $(p=0.04)$ between type of housing and how satisfied the farmers were with the health of the cows. On average $71.4 \%$ of the farmers seemed to be satisfied above medium with the herd health situation (Table 16). Deep bed farmers seemed to be most happy with the health situation. The table also shows that there was a statistically significant association $(p<0.001)$ between farm- 
ers' satisfaction with the cow welfare and the type of housing. Overall $85.2 \%$ of the farmers were satisfied above medium with the welfare of their dairy cows. The farmers found the cows to be very comfortable in deep bed houses, as $100 \%$ were above medium. The correlation between the farmers' satisfaction with health and with welfare was only $r=0.34,(p<0.001)$. This question was not posed in 1983.

\section{Discussion}

\section{Man power}

The farmers' participation in the daily work with the cows (Table 1) has apparently only changed a little during the 12-year period. However, the wives participate in fewer herds today than in 1983. This may be due to the fact that more women are working outside the farms in 1994. In a study of 328 Norwegian dairy herds, Bakken (1981) found that the husband participated in the work in $88 \%$ of the herds, the man and wife did the job in $20.2 \%$ of the herds, and the whole family participated in $10.1 \%$ of the herds. This corresponded well to the Danish results from 1983. Studies by Blom (1981) showed that calves had lower morbidity when the wives participated in the work. This may be the case with dairy cows also, and as such the wives participation is important for the welfare of the cows.

The reduced time spent on milking and feeding in cubicle and deep bed houses compared to tie stall houses in the 1994-study (Table 2) was very likely due to the different housing design, and due to a higher level of mechanization and a more rational way of working in larger herds. Loose house systems usually have milking parlors, and the feeds are provided by truck or other easily handled methods. Comparing tie stall houses with traditional dung channel of the 2 studies, there was a $43 \%$ reduction in time from 1983 to 1994 . This may give the farmer more time for other duties, such as observation of cows for heat, calving and disease.

Another Danish survey, which was carried out by the Danish National Department of Cattle Husbandry (Anon. 1988) in 12000 dairy herds showed that $30 \%$ of the herds had constant hired farm laborers. $17 \%$ hired laborers periodically, and 53\% did not hire extra people at all. Comparison of the 3 studies showed that hiring of laborers has become more common in tie stall farms during the 12-year-periode. National statistics (Anon. 1994) showed that $16.4 \%$ of farmers in all agricultural sectors in 1993 hired permanent laborers, and that it was positively associated with herd size.

The use of relief personnel has increased from 1982 to 1993 (Anon. 1994), e.g to take over the duties of ill farmers, because of extra work in busy seasons, and also because it has become more common for farmers to go on vacation. Tie stall farms were generally smaller than loose housing systems (Table 2). This may be the explanation for the less frequent permanent hire of extra people (Table 3 ). - The economic basis for that may be too low in small herds. On the other hand, when a small herd farmer gets sick, he inevitably needs to call a relief man. This may also be the explanation why tie stall farmers more frequently hired a relief man (Table 4). The importance of whether it is the owner or hired people that take care of the cows with respect to health and welfare is not clear at this stage. It will be investigated in later studies. However, owners are expected to care more for their herds than hired people.

\section{Bedding}

The amount of bedding in 1994 (Table 5) in tie stall houses with open dung channel corresponded very well to the use of $1.5 \mathrm{~kg}$ straw in the 1983-study. This also meet the general recommendations that cows need at least $0.5 \mathrm{~kg}$ straw twice a day (Anon. 1991). The less use of 
straw in tie stalls with slats and gratings compared to the traditional dung channel is solely due to the housing design - i.e. the manure handling system. This is a good example of higher attention paid to eased management and letting the cows pay the price. With little straw, the bed is harder, leading to a higher risk of contusions on hocks, foreknees etc. In a Norwegian study of 328 tying herds where the majority used saw dust (90.3\%), Bakken (1981) also found that the amount of litter mainly varied according to the dung removal system. The large variation among the herds, and especially among tie stall farms using very high amounts of straw, may also indicate that some farmers expected the cows to eat from the bedding. Chopping of the straw has become 10 fold more common during the 11 years. It facilitates a more even distribution of bedding, and the straw passes more easily through the slats and gratings.

Alternatives to traditional bedding are getting more common in the USA. Examples are sand beds and fabric covered mattresses with various types of fillings to be used in tie stall houses as well as in cubicle houses. A sand layer of 15-20 cm usually provides good cushion and drainage (McFarland \& Gamroth 1994). Sand is inorganic, at least in the beginning, and provides a poor environment for growth of bacteria, which can cause mastitis by environmental pathogens. Sand bedding, so far, seems to be an excellent alternative to traditional bedding material in order to reduce cushions on hocks and foreknees of the dairy cows (McFarland \& Gamroth 1994). However, sand may cause technical problems for the manure handling. Mattresses with a fabric cover, typically woven polypropylene or woven polyester, and filled with chopped straw, hay, sawdust, shavings, or even chopped rubber from worn out car tires, are getting common. Rodenburg et al. (1994) compared the cleanliness and the occurrence of hock injuries of dairy cows in 18 Canadian Hol- stein cubicle house systems, 6 herds on mattresses, and 12 herds on rubber mats. They found that cows on mattresses were more clean and had a lower incidence of swellings on the hocks as compared to cows on rubber mats. However, they also mentioned that the results may be confounded, as they did not consider other variables like frequency of cleaning procedures and amount of bedding used in the herds.

The very few heifer cubicle herds that used bedding may indicate an area that needs further welfare research (Table 6).

\section{Water supply}

Apparently almost all (98.2\%) tie stall herds today have installed drinkıng bowls (Table 7). This is a positive improvement for the cows and convenient for the farmers. Danish recommendations for supply of water is a capacity of min1mum $8 \mathrm{l} / \mathrm{min}$ (Anon. 1991). If the tap water pressure is not high enough, the cow may simply not drink water enough as there is a limit to how long time a cow will drınk. This may in extreme cases lead to impaired physiological conditions and eventually to disease. The capacity in the herds in the 1994-study on average seems to be almost twice the recommended level. Farmers' checks of the drinkıng bowls (Table 8) were more frequent and probably also more easily done in loose housing systems than in tie stalls. They are easier to access in loose houses, and there are usually fewer drinking bowls as they generally used troughs.

\section{Manure handling}

Comparison of the present studies (Table 9) show a clear trend towards more automized manure handling. This leaves the farmer physically less loaded and saves time and energy for other duties such as surveillance of the cows. 


\section{Health management routines}

It is an old experience that "looking after the cows" may prevent unwanted incidents, e.g. calving problems, cows fixed under a partition, no water available, and detection of early stages of disease. A Danish survey in 1988 (Anon. 1988) showed that the farmers observed the cows 1.8 times per day. The 3 studies show an increase from 1 daily check of the cows outside the routine working hours in 1983 to $2-2.3$ checks per day in 1994. This is a very positive development. Mechanization may have had a positive impact on farmers surveillance habits. It is very important that it is the same person that checks the cows every day - they get to know the animals better.

As reproduction is essential to the dairy enterprise, it is not surprising that this was the variable the farmers were most concerned about when checking the cows, day as well as night (Tables 10 and 11). The farmers were also concerned about the health condition, which, apart from the more direct signs of disease, was reflected in several of the other signs observed for (Table 10). Faye (1991) found that only $41.0 \%$ of the farmers in 83 French dairy herds had routine checks for cows in heat.

About half (44.1\%) of the farmers stated that the grazing heifers were attended daily. In a similar survey from $1988,60 \%$ of the farmers stated that they looked after the heifers daily (Anon. 1988) This may indicate that fewer farmers looked after the heifers daily in 1994. The Danish law for protection of anımals emphasizes that grazing animals should be looked after regularly (Paulsen 1994). Infrequent attention may have adverse effect on the animals' welfare and result in an economical loss for the farmer. The farmers should be encouraged to attend the heifers daily, whenever possible.

According to the farmers statements, more have become aware of the importance of the length of the dry period. The estimates show an in- crease of about 1 week from 5.7 weeks in 1983 to 6.6 weeks in 1994 . Nutrition of highly pregnant cows at drying off is an important topic also. The present studies indicate an increase from ca. $80 \%$ in 1983 to $95 \%$ in 1994 (Table 12) in the restriction of concentrate and roughage in combination. This is a topic that still needs more research in relation to prevention of production diseases. In a study of 83 French dairy herds, Faye (1991) found that $24 \%$ of the farmers gradually reduced the ration in order to dry the cows off; $47 \%$ dried the cows off abruptly with diet and $28.9 \%$ abruptly without diet.

In 1988 the cows were sheared one or more times per year in $76 \%$ of the herds, and seldom or never in $24 \%$ of the herds (Anon. 1988). This corresponded well to the results of the 1983and the 1994-study. A closer look at Table 13, however, shows that only $21 \%$ of the tie stall farmers in 1994 did not shear the cows. This indicates a slight trend towards a higher shearing frequency. The need to shear the cows in loose housing systems may be smaller than in tie stall houses, because loose cows have more freedom for self grooming and social grooming, and also because loose housing systems generally are colder and with more draught. Cattle has, like other animals, a natural grooming behaviour, which can be practiced under natural free range life, e.g. grazing during summer. However, housing often restrict the natural movement and provides a dirty environment for the cows. It is therefore necessary that the farmer either install facilities or actively groom the cows in order to keep the skin and hair coat in a good condition. In 1988 the cows were groomed manually in $35 \%$ of the herds, with a rotating brush in $19 \%$ of the herds, and seldom or never in $44 \%$ of the herds Anon. (1988). Comparison of the 3 studies shows that farmers during the 11-year period have increased their efforts of grooming from $53.6 \%$ in 1983 to $56 \%$ in 1988, and to $69 \%$ in 1994 in tie stall herds. 
Reasons for a low grooming frequency in cubicle and deep bed houses may be that it is difficult for the farmers to handle loose cows, and also because cows have better possibility for self grooming. A rotating brush seems to be the right choise. Bakken (1981) found that Norwegian farmers groomed the cows at least once a week in $45.0 \%$ of the herds, and once a day in $10 \%$ of the herds.

\section{The farmer and his opinion about the herd}

From 1983 to 1993 the mean age of all Danish farmers was 52 years (Anon. 1994). In 1988 (Anon. 1988) the average age of dairy farmers was 45.6 years. Compared to the present studies a slight decline in the mean age among tie stall farmers was seen. The 1994-results also indicated that it primarily is the younger generation of farmers that use new production systems (loose housing systems). This should also be seen in relation to the expectations to be a farmer 5 years ahead. Farmers of loose house systems are younger and on average have larger dairy herds (Table 2). There is no clear relationship between age of the farmer and welfare of the dairy cows. However, the 1994-study shows that the use of new production methods and housing designs are associated with age. Improvement of the welfare due to introduction of such facilities will primarily take place among the younger generation of farmers. Information about housing designs and welfare to these groups of farmers are therefore extremely important.

The use intensity may be extremely important for the animals. Too high use intensity (too many heat producing units per cubic meter) may reduce the air quality and increase the humidity, particularly in the winter season. As well, too many animals per square meter of floor in loose housing systems may trigger more fights among the cows, and in cubicle houses some may even not have a cubicle to rest in. Such conditions impair the health and wellbeing of the cows. That tie stall farmers felt they had a higher use intensity may be due to the fact that this housing design is the oldest among the 3 farm types. Old tie stall houses often have low ceiling height, narrow stanchions, and narrow stall paths. The reason that loose house farmers often feel there may be room for more cows is important. It should be tressed, that there are as least one cubicle available per cow in cubicle houses, and according to Danish recommendations (Anon. 1991) there should be 4-6 $\mathrm{m}^{2}$ per cow in deep bed houses.

The low correlation between farmers' opinion about the health and welfare conditions of the cows (Table 16) indicate that they differentiated between the 2 concepts. However, it is not, on this basis, possible to judge whether the farmers consider health to be only one among several parameters that are part of the welfare concept, or if they biologically consider health and welfare to be independent.

In studies of animal welfare and well-being, the analogy postulate is often taken for granted, namely that anımals percieve in the same way as humans. For example, it is generally assumed that the cows feel well and in some ways benefit positively when groomed, and when lying in a clean, dry and soft tie stall or cubicle. If this assumption is correct, it may be accepted to use explanatory variables, like grooming and bedding, as indicators of welfare, as well as information about disease, behaviour and physiology.

The reader is referred to the first paper by $\mathrm{Al}$ ban \& Agger (1996a) for a discussion of data quality and assessment.

\section{Conclusion}

The following can be concluded:

- The husbands still do the major part of the work on the farms; the wives do almost not 
work on the farms any more, and it has become more common to hire laborers and relief men.

- The time spent on milking and feeding the cows has been reduced approximately $40 \%$ during the period from 1983 to 1994.

- Straw is still the preferred bedding material for cows. However, only $37 \%$ of the farms used bedding material for the heifers.

- The cows are surveilled on average twice a day in 1994 compared to once a day in 1983.

- The farmers stated they were generally willing to check the animals at night, particularly calving cows.

- The farmers apparently check pasturıng heifers less frequently in 1994 than in 1988.

- The dry cow period seems to have increased from 5.7 weeks in 1983 to 6.6 weeks in 1994.

- The farmers differentiated between health and welfare.

- It can generally be concluded that management variables differ among the 3 housing designs: tie stall houses, cubicle houses, and deep bed houses. This justifies the descriptive strategy of the 2 datasets.

\section{Acknowledgement}

The authors want to thank the Danish Agricultural Advisory Centre for providing farmers' addresses, the farmers for good cooperation, and Annelise Ito, Christına Ejlersen and Lartey Lawson, Department of Anımal Science and Anımal Health, Royal Veter1nary and Agricultural University, Frederiksberg, Denmark, for excellent technical assistance. The study was funded by the Danish Ministry of Agriculture, grant no. VEL92-KVL-8.

\section{References}

Alban L, Agger JF Welfare in Danısh Dairy Herds 1 Disease management routines in 1983 and 1994. Acta vet. scand. 1996a, 37, 49-63.

Alban L, Agger JF Welfare in Danish Dairy Herds 2. Housing systems and grazing procedures in 1983 and 1994. Acta vet. scand. 1996b, 37, 65-77.
Anonymous. Produktionssystemer og produktionsmetoder 1 kvægbruget. Landskontoret for Kvæg. (Production systems and production methods in the cattle husbandry. The Danish National Department of Cattle Husbandry). Århus, Denmark $1988.17 \mathrm{pp}$.

Anonymous. Indretning af Stalde t1l Kvæg - Danske Anbefalinger. (Design of cattle houses - Danish recommendations) Danish Agnicultural Advisory Center, Aarhus, Denmark 1996

Anonymous. Landøkonomisk oversigt 1994. (Agr1cultural statıstics 1994). De Danske Landboforeninger, Copenhagen, Denmark 1994 pp 12-19.

Bakken G. A survey of environment and management in Norwegian dairy herds with reference to udder diseases. Acta agric. scand. 1981, 31, 4969

Blackshaw JK. Objective measures of welfare in farming environments. Aust. vet. J. 1986, 63, 361-364.

Blom JY. Enzootısk pneumonı hos kalve: Epıdemı$\log _{1}$ og profylakse. (Enzootic pneumonia in calves. Epıdemiology and prophylaxis). The Royal Veterinary and Agricultural University, Frederıksberg, Denmark. Thesis $1981101 \mathrm{pp}$.

Bramley $A J$ The control of environmental mastitis. Proc 24th Annual Meetıng National Mastitıs Counc1l 1985, 4-17

Broom DM Indicators of poor welfare. Br. vet. J. 1986, 142, 524-526.

Broom DM. Assessing welfare and suffering Behav1oral Processes, 1991, 25, 117-123.

Broom DM, Johnson KG Stress and anımal welfare. Chapman \& Hall, London, $1993211 \mathrm{pp}$.

Christensen $R \cdot$ Log-linear models Springer-Verlag, Berlın, 1990. 408 pp.

Dodd FH, Higgs TM, Bramley AJ Cubicle management and colıform mastitıs Vet. Rec 1984, 114, 522-523.

Duncan IJH, Dawkins MS The problem of assessing "well-being" and "sufferıng" in farm anımals. In. Smidt D (ed.). Indicators relevant to farm animal welfare. A Seminar in the CEC Programme of Coordination of Research on Anımal Welfare, Mariensee, Nov 1982. Martınus Nijhoff Publıshers, Boston, 1983. pp 13-24.

Ekesbo I Disease incidence in tied and loose housed dairy cattle. Acta agr. scand. 1996, Suppl. 15, 79 pp.

Faye $B \cdot$ Interrelationships between health status and farm management system in French dairy herds. Prev. vet. Med. 1991, 12, 133-152. 
Francis $P G$, Sumner J, Joyce DA The influence of the winter environment of the dairy cow on mastitis. Bovine Pract. 1981, 16, 24-27

Hogan JS, Smith KL A practical look at environmental mastitis. Comp Cont. Educ. Pract. Vet. 1987, 9(10)· F341-346

Jarrett JA Environmental effects on mastitis and milk quality. In. Jarrett JA (ed.). Veterınary Clın1cs of North Amenica. Large Anımal Practice. Symposium on Bovine Mastitıs. WB Saunders Co. Philadelphia 1984, 6, 371-375.

McFarland DF Freestall Housing Guidelines: Design detalls to enhance management 2nd Western large herd darry management conference, Las Vegas, Nevada, April 5-8, 1995 pp 89-102

McFarland DF, Gamroth $M J$ Freestall designs with cow comfort in mind. 33rd annual meetıng, National Mastitıs Counc1l, INC, Orlando, Florida 1994 pp 270-285

Paulsen $J$ Dyrebeskyttelse. (Anımal protection) The Danısh Veterınary Association and The Danish Anımal Welfare Society, Copenhagen, Denmark 1994, 388 pp.

Riemann H, Larssen RB, Simensen E Ketosis in Norwegian dairy herds - some epıdemiological associations Acta vet. scand. 1985, 26, 482-492.

Rodenburg $J$, House HK, Anderson NG Free stall base and bedding materials: Effect on cow comfort. 33rd annual meetıng, National Mastitis Council, INC, Orlando, Florida 1994. pp 286291.

Sandøe P, Simonsen $H B$ Assessing anımal welfare. Where does science end and philosophy begin? Anımal Welfare 1992, 1, 257-267

SAS Institute Inc · SAS/STAT User Guide, Version 6 (4th ed ), Cary, NC 1989.

Simonsen $H B$ Velfærdsvurderıng i intensıv husdyrbrug. (Evaluation of welfare in intensive animal husbandry). Ugeskrift for Jordbrug 1982, 25-27.

Simonsen $H B$ : Velfærdsbegrebet (The welfare concept) In Husdyrets og landmandens velfærd 1 fremtıdens teknologiske produktionssystemer (Welfare of production animals and farmers in future high technological production systems). Akademiet for de Teknıske Videnskaber, Denmark 1990

Simonsen $H B$ Vurderıng af dyrs velfærd (Assessment of the welfare of anımals). In Sandøe P, Simonsen HB, Jensen KH, Krohn CC, Hagelsøe M, Nørgaard-Nielsen G, Hansen SW, Bjerregaard C (eds.): Etık, velfærd og adfærd 1 husdyrbruget (Ethics, welfare and behaviour in anımal husbandry). Landbrugets Informationskontor, Århus, Denmark 1993, 17-28

Smith KL, Todhunter DA, Schoenberger PS Environmental mastitis: Cause, prevalence, prevention. J. Dairy Sc1 1985, 68, 1531-1553.

Thomas CB, Jasper DE, Rollins MH, Bushnell RB, Carroll EJ Enterobacteriaceae bedding populations, rainfall and mastitıs on a California dairy. Prev. vet. Med 1983, 1, 227-242

\section{Sammendrag}

Velfard 1 danske kvagbescetninger 3 Sundhedsstyring og generelle rutiner i 1983 og 1994

Denne artıkel beskriver tredje del af resultaterne af danske spørgeskemaundersøgelser 1152 malkekvægbesætnınger 11983 og af 2148 malkekvægbesætnınger 1 1994. Der fokuseres på arbejdsrutıner relateret til sundhedsstyrıng og arbejdsrutıner relateret t1l koens nærmiljø. Faktorerne er grupperet 1 arbejdskraft, strøelse, vandforsynıng, udmugning, sundhedsstyrıngs-rutıner, samt spørgsmål vedrørende landmanden og hans syn paa køernes sundhed og velfærd Resultaterne viser, at besætnıngsejeren udførte størstedelen af arbejdet 1 besætnıngerne Fast arbejdskraft blev især hyret 1 løsdriftstalde, mens det var mere almindeligt at hyre afløsere 1 bindestalde dvs. i de generelt mindre besætninger Til fodrıng og malkning blev der gennemsnitligt brugt 5,2 min pr ko pr. dag 1 løsdriftstalde, mod 9,9 min 1 bindestalde. Materialet antyder endvidere en reduktion på $43 \% 1$ tıden anvendt tıl malkekøerne 1 bindestalde 1 perioden fra 1983 til 1994 Som strøelse blev der primært anvendt halm, men 1 meget varierende mængder. Der blev kun anvendt strøelse til kvierne $145,5 \%$ af besætnıngerne. Vandforsynıngen forekom at være installeret $\mathrm{i}$ alle besætnınger, og udmugnıng var stærkt automatıseret. Landmændene så tıl køerne gennemsnitlig 2 gange dagligt uden for fodrıngs- og malketıderne. Landmændene så specielt efter tegn på brunst, sygdom, kælvning og unormal rejse- og læggeadfærd Resultaterne viser også, at $87,7 \%$ af landmændene 1 bindestalde og 80,8\% 1 sengebåsestalde ville se til køerne om natten, specielt 1 forbındelse med kælvnıng. I dybstrøelses-besætnınger angiver kun 58,5\% af landmændene, at de står op om natten for at se til køerne Græssende kvier blev kun t1lset dagligt $133.7-56.9 \%$ af besætningerne. Landmændene angav, at de var meget opmærksomme på betydningen af køernes goldperiode -1 gennemsnit 
for alle besætnınger var den steget ca.1 uge fra 5,7 1 1983 til 6,6 uger 1 1994. Landmændene var generelt t1lfredse med køernes sundhedst1lstand og velfærd.
Svarene antydede også, at landmændene skelnede mellem de to begreber, 1det korrelationen mellem sundhed og velfærd kun var $r=0,34(p<0001)$.

(Recelved June 30, 1995, accepted November 1, 1995)

Reprints may be obtained from JF. Agger, Department of Anımal Science and Anımal Health, Divisıon of Ethology and Health, The Royal Veterınary and Agrıcultural Unıversity, Bülowsvej 13, DK-1870 Frederiksberg C, Denmark E-ma1l: JFA@KVL.DK, FAX +4535283022. 